\title{
TJP1 wt Allele
}

National Cancer Institute

\section{Source}

National Cancer Institute. TJP1 wt Allele. NCI Thesaurus. Code C114823.

Human TJP1 wild-type allele is located in the vicinity of $15 q 13$ and is approximately $269 \mathrm{~kb}$ in length. This allele, which encodes tight junction protein ZO-1, is involved in the signal transduction and the formation of cell-cell junctions. 